\title{
ŘETÍZEK SE ZÁVĚSKY Z HRADU VEVEŘí U BRNA
}

\author{
ZDEŇKA MĚCHUROVÁ - ALENA SELUCKÁ
}

\begin{abstract}
Abstrakt: Ve sbírkách archeologie středověku Moravského zemského muzea je uložen řetizek z barevného kovu sestavený z pěti spirálek a opatřený pưvodně zřejmě deviti závěsky, z nichž se zachovaly dva neurčitelné zlomky, jedna miniatura kliče a jeden neúplný, pưvodně snad funkční kliček. Materiálové analýzy ukázaly použití mosazného drátku (slitina tombak s nizkým obsahem zinku) o různé tlouštce pro zhotoveni jednotlivých částí řetízu. U jednoho z dochovaných závěsků - železného kličku - bylo identifikováno pájení, prípadně plátování mědí.

Přesné misto a dobu nálezu předmětu lze hledat na hradě Veveři, při opravách komunikace pod hradem $n e ̌ k d y v$ 70. letech 19. století, za majitelky kněžny Heleny Ypsilanti de Sina. Archeologické analogie nás zaváději už do pravěku do etnicky germánského prostředí. V přialpské oblasti se v novověku objevují zvláštní růžence se závěsky coby specifická forma souboru amuletů, na nichž se kromě křest'anských symbolů vyskytuji také apotropaika, chráníci majitele před zlými silami. Takové retízky, většinou jako náramky, existují $i$ v našem dnešním světě, udržuji si svou upomínkovou či ochranitelskou funkci do současnosti. Známy jsou v drahém kovu jako luxusní šperk dospělých, nebo jako dětská bižuterie opatřená beruškami, čtyřlístky, kličky či srdičky.
\end{abstract}

Klíčová slova: šperk-novověk-analytické metody.

\section{Chain with Pendants from Veveři Castle, near Brno}

Abstract: Medieval archaeology collections of the Moravian Museum hold a chain made of a non-ferrous metal consisting of five spirals and originally probably provided with nine pendants of which two unidentifiable fragments have survived. The first is a miniature key and the second an incomplete key that might have once been functional. Material analyses confirmed the use of copper wire (tombac alloy with a low zinc content) of different thickness for the individual parts of the chain. Soldering (and possibly copper-plating) was identified with one of the pendants, the iron key.

The find comes from the Veveri castle and was excavated during the repairs of the communication below the castle in the 1870s when the castle was owned by Countess Helena Ypsilanti de Sina. Archaeological analogies go back to prehistory and the German ethnic environment. In the modern age, special rosaries with pendants making up a specific set of amulets appeared in the Alpine region. Apart from Christian symbols, the pendants included apotropaic ones protecting the owner from evil powers. These chains, often worn as bracelets, still exist today and have maintained their keepsake and protective function. They are usually made of precious metals in the form of luxury jewellery for adults, or as children's charm bracelets featuring ladybirds, four-leaf clovers, keys and hearts.

Key words: jewellery - modern age - analytical methods.

\section{Úvod}

V nedávné době byly zveřejněny rozbory zajímavých pásových řetězů ze 16 . století, uložené ve sbírce archeologie středověku Moravského zemského muzea. Tematicky volně by se k nim mohl přiřadit další předmět z této sbírky, tentokrát zřejmě neúplný náhrdelník - řetízek z obecného kovu s několika závěsky, patřící k muzejně nejstarším sbírkovým předmětům tohoto pracoviště. Dle následujících zjištění pochází z hradu Veveří a upoutal naši pozornosti při dodatečné evidenci staré sbírky.

Tvoří ho šest spirálek o délce ca $4 \mathrm{~cm}$, v jejichž spojeních navazují další kratší spirálky, střídavě jedna a dvě s osmičkovitým očkem pro zavěšení různě tvarovaného závěsku; ve dvou prrípadech jde zjevně o větší a menší klíček, materiálem je dosti zkorodované železo. Větší klíček mohl být zřejmě funkční, jeho dřík je dutý a hlavice prolamovaná zřejmě do tř́i otvorů, zachovány jsou pouze dva z nich. Na dalších dvou spirálkách jsou zavěšeny zbytky opět železných, ale již blíže neurčitelných zlomků závěsků, pět spirálek má spojovací očka prázdná. Sponu náhrdelníku tvoří dvojité protáhlé očko, kterému chybí protilehlý háček na zapnutí, zřejmě i s částí řetízku. Rozměry: celková délka $24 \mathrm{~cm}$, délka spony $6 \mathrm{~cm}$, délka zachovaných klíčků 3 a $2 \mathrm{~cm}$. 


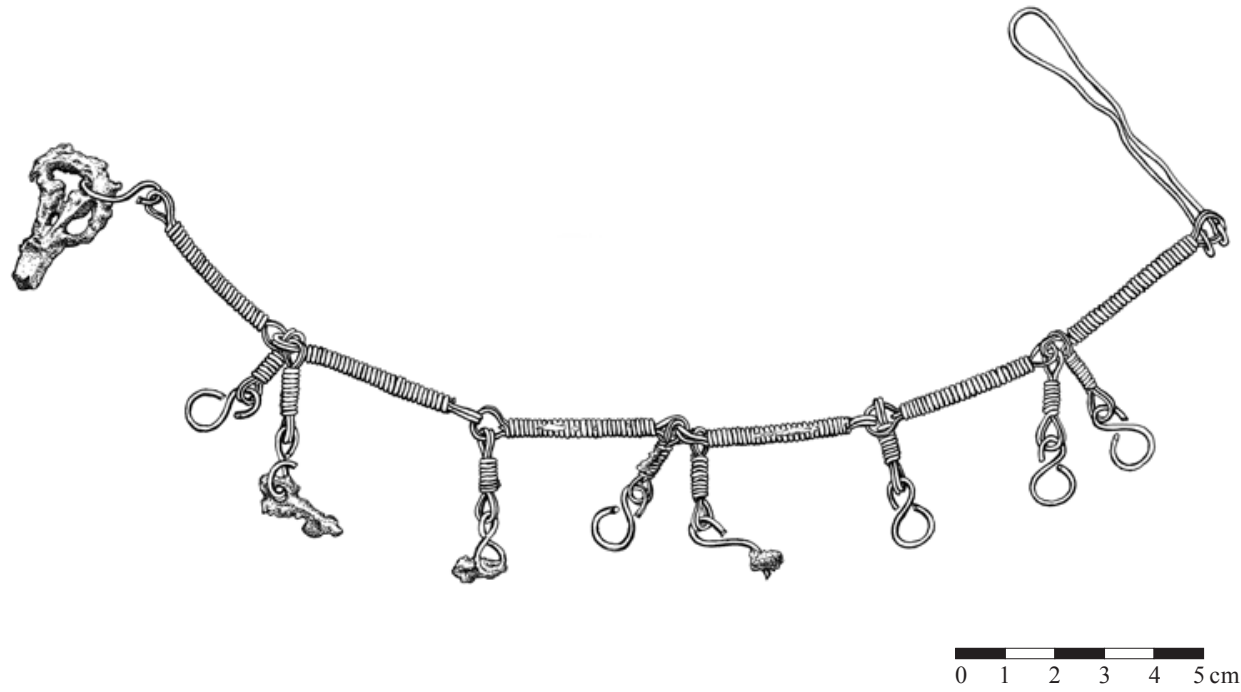

Obr. 1. Řetízek se závěsky z hradu Veveří u Brna. Kresba T. Jankủ.

Abb. 1. Kettchen mit Anhängern von Burg Eichhorn bei Brünn. Zeichnung T. Janků.
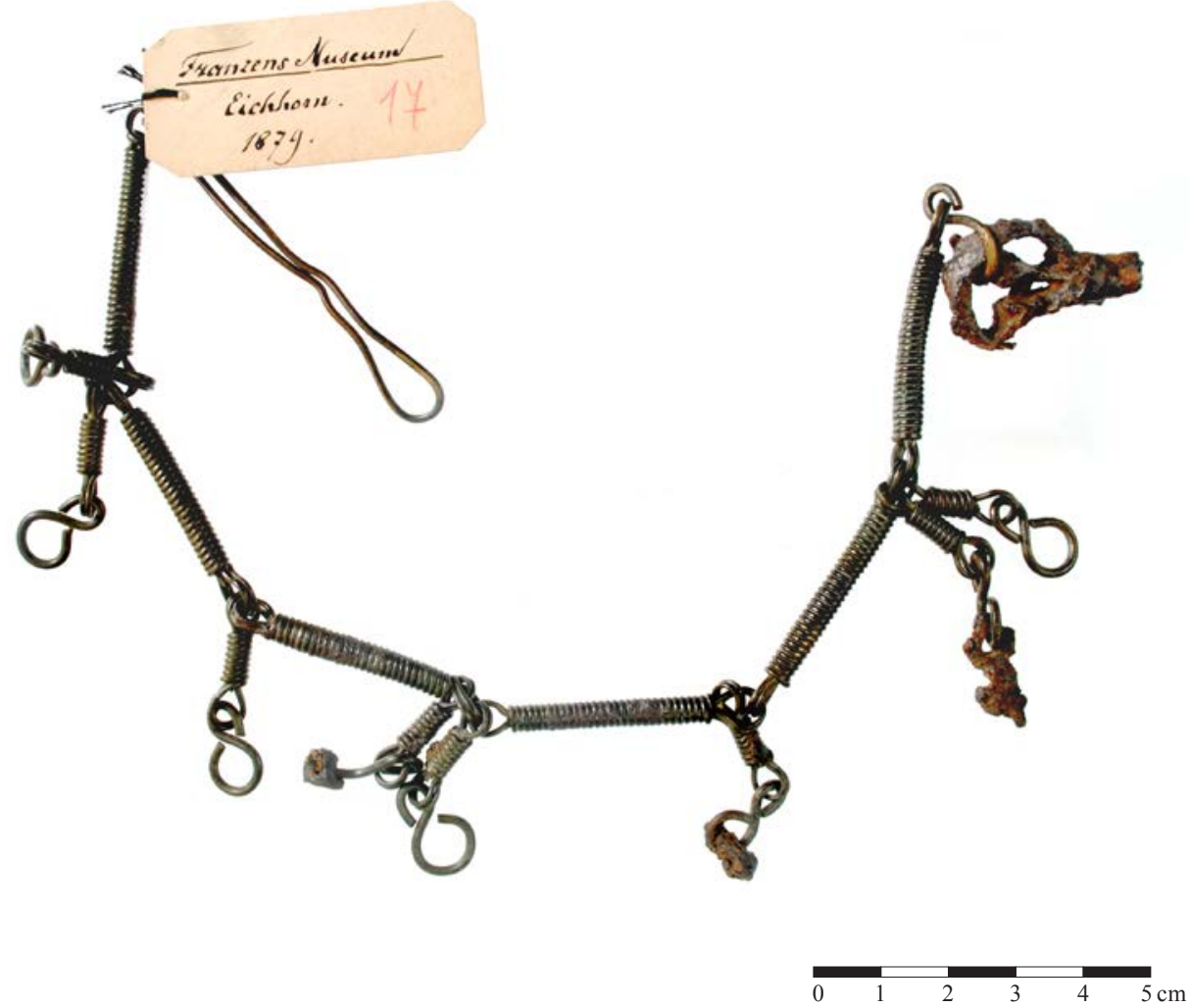

Obr. 2. Řetízek se závěsky z hradu Veveří u Brna. Foto $S$. Doleželová.

Abb. 2. Kettchen mit Anhängern von Burg Eichhorn bei Brünn. Foto S. Doleželová. 


\section{Nálezové okolnosti}

Místo nálezu je uvedeno na původním štítku zavěšeném na záponě. Obsahuje text v němčině „Franzens Museum, Eichhorn. 1879“. Červenou pastelkou připsané číslo 17 nasvěděuje, že se předmětem někdy v 50. letech minulého století zabývala dr. Věra Hochmanová, v té době kurátorka sbírek prehistorického oddělení. Údaj „Eichhorn“, česky Veveří, nám neposkytuje jednoznačnou informaci o lokalitě. Mohlo by jít nejen o hrad Veveří, ale také o brněnskou ulici Veveří. O bližších nálezových okolnostech se naštěstí dozvídáme ze starobylých Pamětí panství Veverského, sepsaných Karlem Eichlerem, farářem z Veverské Bítýšky (Eichler 1891, 18-19), a tato zpráva nás už zřetelně směruje na hrad Veveři. ${ }^{1}$ Autor dokonce upřesňuje lokalizaci na okolí svahu nad říčkou Veverkou v souvislosti s líčením nedobytnosti hradu (strmé srázy, řičcky Švarcava [Svratka] a Veverka v hlubokých údolích; obr. 3). Na straně $\mathrm{k}$ Veverce, v místě méně přírodně chráněném byl prý hrad stupňovitě obehnán několika zdmi. Za majitele hradu knížete Ypsilantiho (v 70. letech 19. století) „byl tam park urovnáván, vybráno prý bylo něco těch zdí až do základů. I nalezeno při tom množství rumu, uhli a korýtkové křidlice, z čehož je patrno, že hrad kdysi byl kryt a chránén“ (Eichler 1891, 18). Autor pokračuje podrobným popisem nálezů: „Tamtéž nalezeny železné špice šipů dvojího tvaru, jedny pleskaté podoby vrbového listu, jiné massivně čtverhranné a pod hrotem vypouklé, pak ostruhy, třmeny, kusy železných zbrani a brnění, kusy kouli dutých, zlámaný klíč a konečně bronzové pletivo. Pletivo to drátěné - bývalý snad řetizek na krk nebo ozdůbka jiného účele - pozůstává ze šesti článků délky 4 centimetrů, závitkovitě drátem ovinutých; kde články se spojuji, visí stř́davě jeden nebo dva menši články asi $3 \mathrm{~cm}$. dlouhé, podobně drátem ovinuté, které $v$ ouškách osmičce podobných (S) nesly přivěsky, z nichž zachovaly se pouze dva úlomky a jeden malinkýkličiček. Zvláštností při tom je, že prrivěskyjsou železné, kdežto drát ostatníje spěžový. Jako sponka je na jednom konci kousek železa formy neurčitelné, a na druhém drátěné oko $6 \mathrm{~cm}$ dlouhé. Celá ta ozdoba řetízková má tudiž 34 cm délky a je patinovaná.“(Eichler 1891, 18-19, obr. na s. 89).

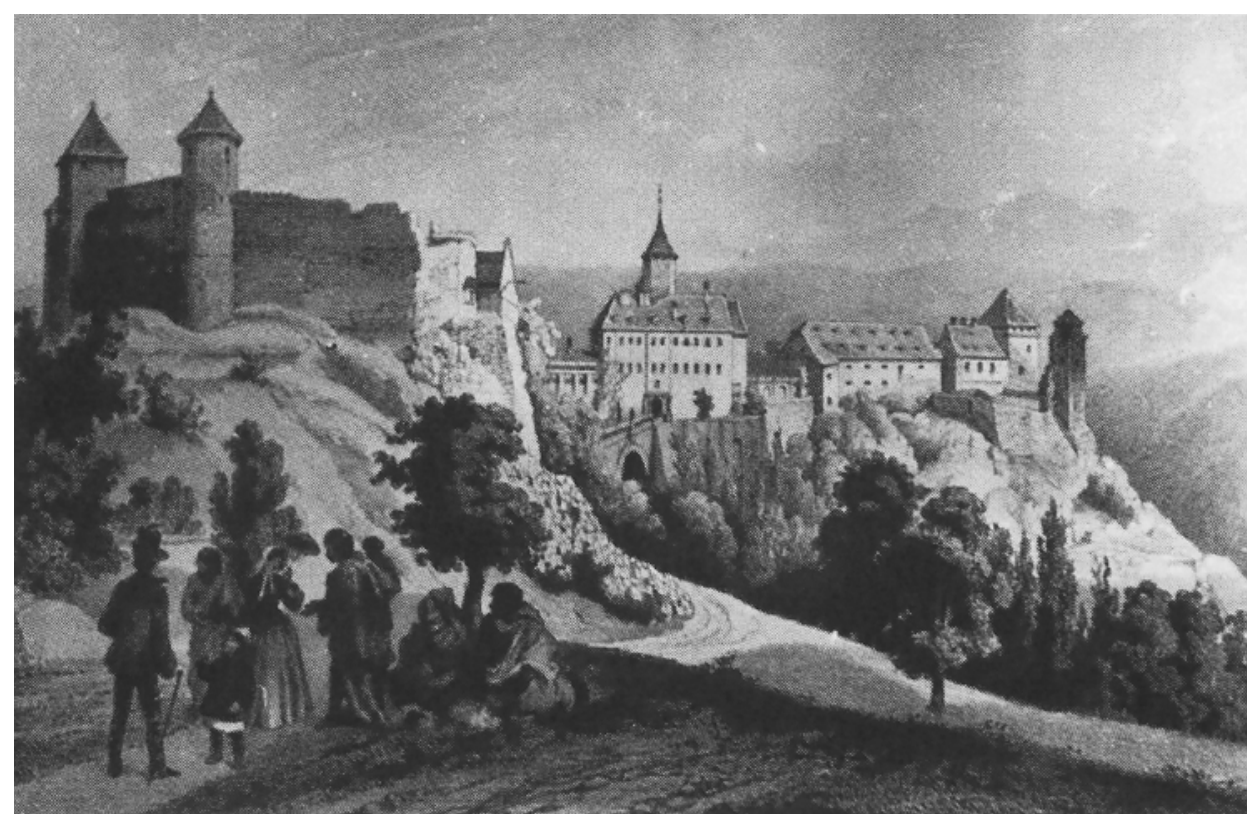

Obr. 3. Hrad Veveří, celkový pohled od východu, Kalivodova fotografická reprodukce. Podle Vitula-Stránská 2006,12 , obr. 14. Abb. 3. Burg Eichhorn, Gesamtansicht von Osten, fotografische Reproduktion von Kalivoda. Nach Vitula-Stránská 2006, 12, Abb. 14.

1 Za informaci o tomto prameni děkujeme Mgr. Pavlíně Pončíkové, pracovnici NPÚ, územní pracoviště Brno, hrad Veveří. 
Tyto předměty uschoval zahradník hradu Veveří Adolf Riesemann a následně byly darovány Františkovu muzeu v Brně. „Nálezy ty, dle dobrozdáni kustoda Františkova muzea Morice Trappa, pocházejí z počátku 15. nebo z konce 14. století, dutá koule však z doby pozdějši." (Eichler 1891, 19).

M. Trapp $(1879, \mathrm{CV})$ nálezové okolnosti a časové souvislosti upřesňuje. Ve vrcholném létě let 1872 a 1873 došlo v okolí hradu Veveří k takové průtrži mračen, že se říčka Veverka rozvodnila a poničila nejen zrrízené zahradní a parkové plochy, ale částečně strhla i veřejnou cestu. $V$ důsledku toho začaly práce na přeložení cesty, a to tak, že v místě první zatáčky říčky Veverky, na jejím pravém břehu bylo nutno odstranit skálu s malou plošinou nahoře. Přri těchto rozšiřovacích pracích byly učiněny zajímavé nálezy. U paty starého zámku, na jeho jižní straně se přišlo při odkopání základů v nevelké hloubce na mocnou vrstvu sutin a uhlíků, evidentně stopy bývalého požáru. Podle Trappa právě v těchto sutinách byly nalezeny šipky, ostruhy a další výše zmiňovaná militaria, ovšem na jiném místě „des alten Schlossberges unter tiefem Brandschutte“ byl nalezen „ein Drahtgeflecht aus Bronze“. Tolik se lze s maximální přesností dozvědět o lokalizaci nálezu řetízku se závěsky.

Bohužel další zde zmiňované nálezy, které by mohly tvořit nálezový celek z hradu Veveří, se ve staré sbírce historické archeologie nevyskytují. O dějinách hradu Veveří, jeho majitelích i stavebních úpravách nejnověji a detailně píše D. Hodeček (2000). Potvrzuje, že zásadní parkové úpravy v okolí hradu a výstavba dvou zimních zahrad byly provedeny za kněžny Heleny, rozené Sinové, vnučky bývalého majitele podnikatele Jiřího Šimona Siny a manželky řeckého vyslance ve Vídni Řehoře Ypsilantiho (Hodeček 2000, 253). Tehdy pravděpodobně mohlo dojít k nálezu zmiňovaných předmětů (obr. 4).

\section{Soubory amuletů v historii}

Spirálkový řetízek se závěsky evokuje souvislost se souborem šperků i amuletů napojených na náhrdelník nebo náramek, který se jakožto apotropaikum s ochranitelským či kouzelným významem objevuje v toku dějin mnohokrát (Čermáková 2009, 187-195). Specifické nošení symbolických předmětů je známo u západních Germánů - Alamanů (ještě před nástupem křest’anství) - řemínek či řetízek upevněný na opasku tvořil součást jejich ženského kroje (Čermáková 2009, 189). Jako závěsky zde fungovaly amulety, šperky i skutečné nástroje (prŕírodniny - křištál,

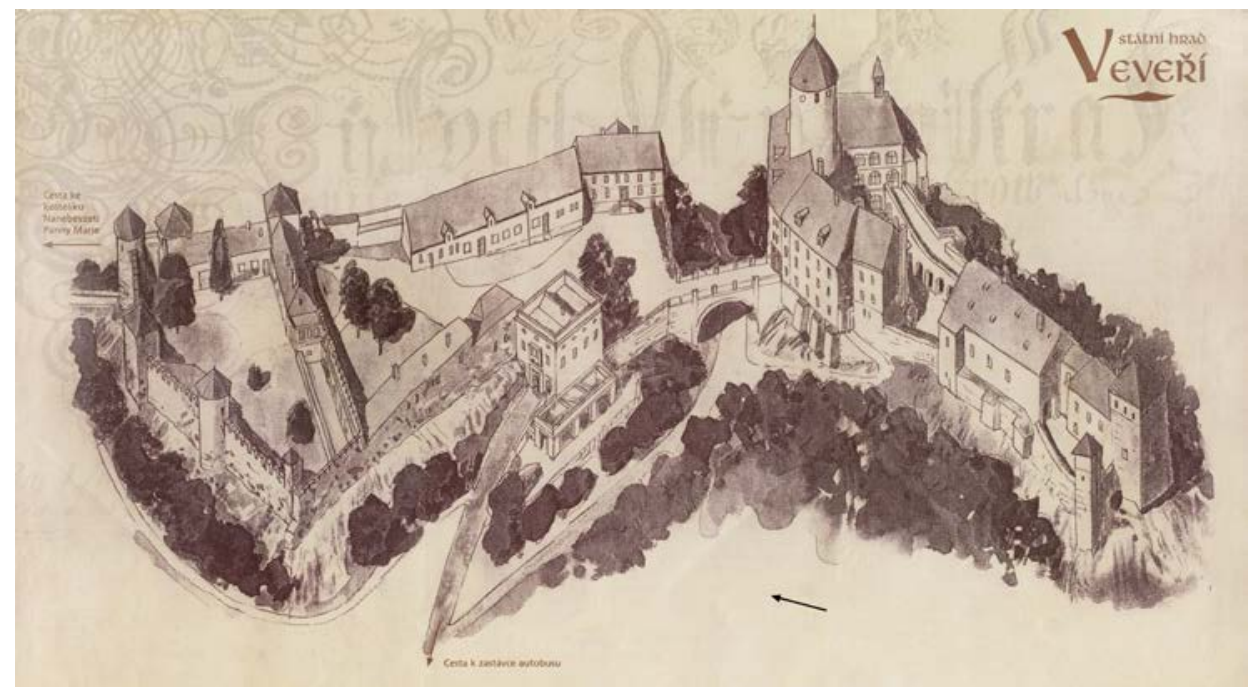

Obr. 4. Plánek hradu Veveří s uvažovaným místem nálezu vyznačeným šipkou. Podle informačního letáku hradu Veveří. Abb. 4. Planskizze von Burg Eichhorn mit durch einen Pfeil gekennzeichnetem, in Betracht gezogenem Fundort. Laut einem Infoflyer von Burg Eichhorn. 
skleněné perly, mušle, nože, nůžky, přesleny, hřebínky, často též právě klíče). Jiným kulturním prostředím je Kyjevská Rus, kde se soubory amuletů vyskytují v mohylách 11. a 12. století jako pohanské přežitky. Jde o kovové figurky koníčků, ptáků, opět klíče, hřebínky, nože, rolničky, které při zavěšení na řetízcích mohly zvonit, a tak zvyšovat svůj magický účinek. V novověku představují specifickou formu souboru amuletů růžence 18.-19. století z přialpských oblastí (obr. 5). Vedle přívěsků křest’anského charakteru (křrižky, ostatky svatých) obsahují také některé kuriozity (vlčí zub, mléčné zuby, stará mince, ulita), a tak se znovu svou skladbou přibližují předkřest’anským raně středověkým soupravám amuletů. Dokonce i 20. století je poznamenáno vztahem k jakýmsi souborům amuletů, které nosíme zavěšeny většinou na náramku a představují náš „osobní kód“ (znamení zvěrokruhu, medailonek) či symboly štěstí a lásky (čtyřlístek, podkova, srdce, slunce). U dospělých bývají provedeny v drahém kovu jako honosný šperk, ale mnohé jsou určeny jakoby podvědomě ,pro ochranu“ dětským uživatelům, a pak jde o tzv. žužu př́věsky s květinami, beruškami, klíčky, podkůvkami aj.

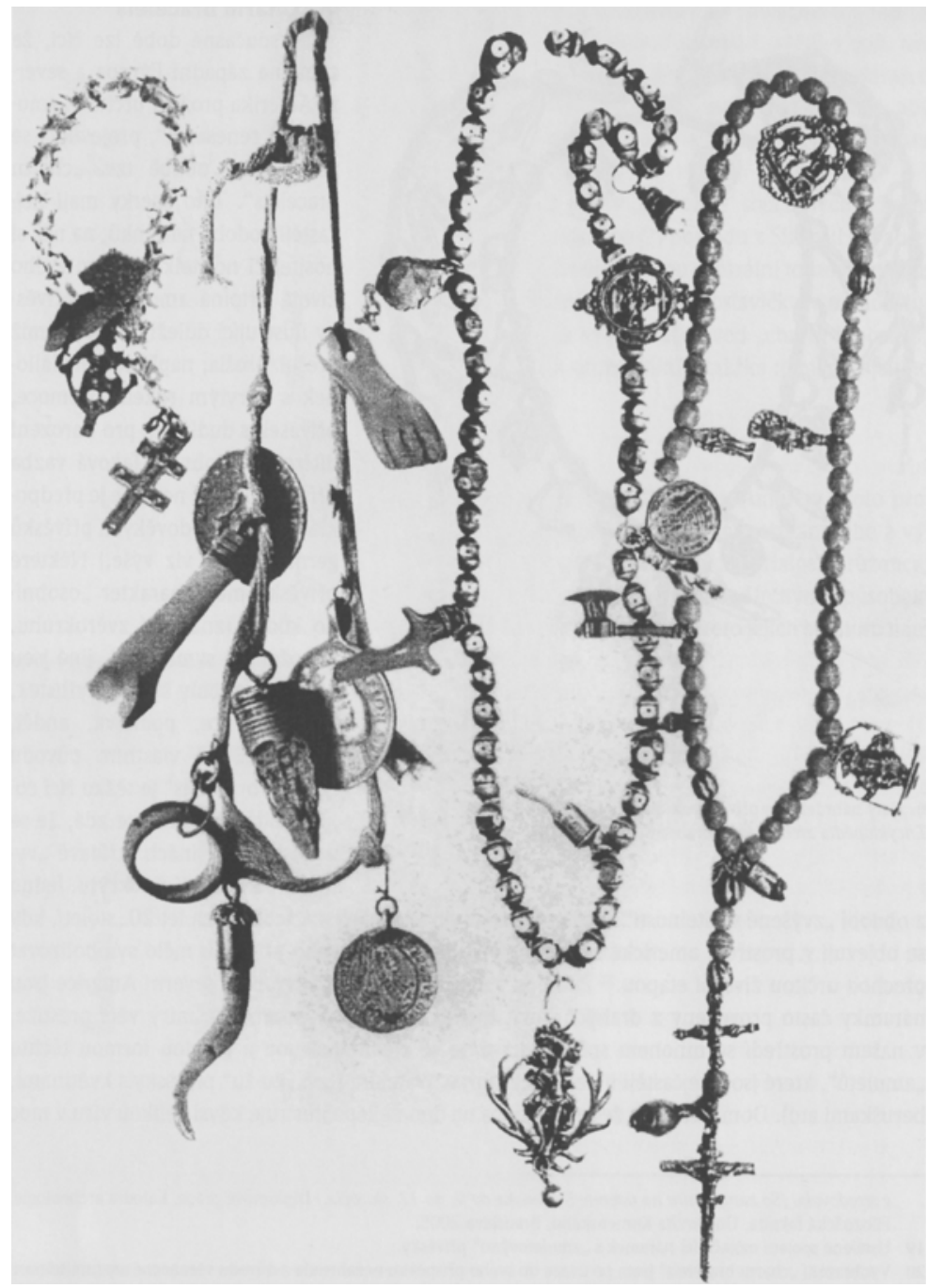

Obr. 5. Růžence přialpských oblastí. Podle Čermáková 2009, 193, obr. 5.

Abb. 5. Rosenkränze aus dem Alpenumland. Nach Čermáková 2009, 193, Abb. 5. 


\section{Klíče}

Vidíme, že symbol klíče se v podstatě prolíná všemi obdobími výskytu těchto řetízků s amuletovými závěsky. Nejinak je tomu v našem př́ípadě; jde evidentně o dva klíče. Větší z nich sice není úplný, ale naznačuje zachovanou částí dutého dříku, že máme před sebou skutečně funkční klíček, zřejmě k nějaké schránce, truhličce, šperkovnici. Hlavice (oko) klíče je poškozená, ale plochý ovál je zřetelně dělen do tří pravidelných polí, z nichž jedno postranní chybí. Předmět můžeme porovnat s typologií středověkých klíčů, kterou sestavil R. Krajíc (1991, 328-333) a rozpracoval při publikaci kovového inventáře ze Sezimova Ústí (Krajíc 2003, 87-97). Podle této typologie se řadí mezi klíče otočné, které se (co se terminologie týče) skládají z oka, dříku a brady (zubu). Chronologicky je Krajícův soubor řazen od druhé poloviny 13. století do roku 1420, kdy je doložen záměrný násilný zánik městečka požárem (Richter-Krajíc 2001, 6). Otočný klíč se zdobně utvářeným vnitřkem oka, které je od dutého dř́́ku odsazeno prstencovou patkou, náleží $\mathrm{k}$ typu XII s datováním do druhé poloviny 14. století až k roku 1420. V případě nálezů z jiných lokalit samozřejmě není důvod omezovat dobu trvání konkrétním letopočtem, takové klíče existovaly určitě i v mladším období. Pokud se týká účelu klíče, zajímavý je Krajícův údaj o používání těchto klíčů pro nepřenosné i závěsné zámky (Krajíc 2003, 91), které tudíž mohly sloužit též u rozměrnějšího nábytku.

Ve druhém případě je klíč tak miniaturní, že je zde jasná pouze symbolika klíče (uzamykání, otevírání duše, srdce, tajemství atd.). Přesto lze u něj rozeznat všechny části klíče, oko, dř́ik i bradu.

\section{Řetízek}

Spirálkový řetízek se skládá ze šesti jednotlivých spirálek, tvořících vlastní náhrdelník, a osmi kratších kusů, které umožňují zavěšení přívěsků, střídavě vždy jedna a dvě spirálky doplněné osmičkovitými háčky pro uchycení přívěsků. Kratší spirálky s osmičkovitými háčky na zavěšení přívěsků jsou na rozdíl od vlastních př́ivěsků vyrobeny z mosazi. Rovněž uzávěr v podobě podlouhlého dvojitého oka je netradiční. Pravidelnost spirálek ukazuje na značnou přesnost provedení, skoro až strojovou výrobu. Totéž lze říci o vytvarování osmičkovitých mezičlánků. Nelze ovšem vyloučit, že na mladším, novověkém řetízku byly zavěšeny starobylé, archaické, pro majitele cenné, a proto uchovávané předměty.

\section{Analogie}

Starobylost užívání spirálek coby článků řetězu naznačuje, zdá se, hluboce pravěká analogie. V roce 1892 objevil rolník W. Janssen v rašeliništi u severoněmeckého Lorupu nákrčník (o celkové délce $41 \mathrm{~cm}$ ) složený z podobných pravidelných spirálek s dvanácti terčíkovitými závěsky vyrobený ze zlatého drátu. Nejen nákrčník, ale celý depot zlatých předmětů byl vrostlý v rašelině a obsahoval další volné spirálky, otevřené náramky typu $\mathrm{C}$ a duté trubičky (Borchers 1968, 30, Taf. I:1). Soubor byl odkoupen městským muzeem v Osnabrücku. Patřily k němu také jantarová perla (s přisuzovanou ochrannou mocí, stejně jako křištálu) a prsten, které se bohužel ztratily. Celek byl několikrát zpracováván a řešilo se jeho datování (byl srovnáván s mykénským zlatým pokladem a v té souvislosti se ukázala oblíbenost spirálovitých ozdob v tomto období - plochých terčíků, náušnic, prstenů, brýlovitých spon - ze zlatého drátu). Přestože nebylo $\mathrm{v}$ tomto směru řečeno poslední slovo, podle provedených materiálových rozborů zlata badatelé usoudili, že jde o nález z mladší doby bronzové, doby popelnicových polí (obr. 6). Je tedy možné, že pravidelnost spirál, o níž jsme hovořili výše, není jen otázka uvažované strojové výroby, ale také určité zručnosti a nápadu využití jednoduchých pomůcek (např. obtáčení drátku z poměrně měkkého kovu kolem rovné tyčinky pevného průměru), a tedy vůbec nemusí být vodítkem pro chronologii. 


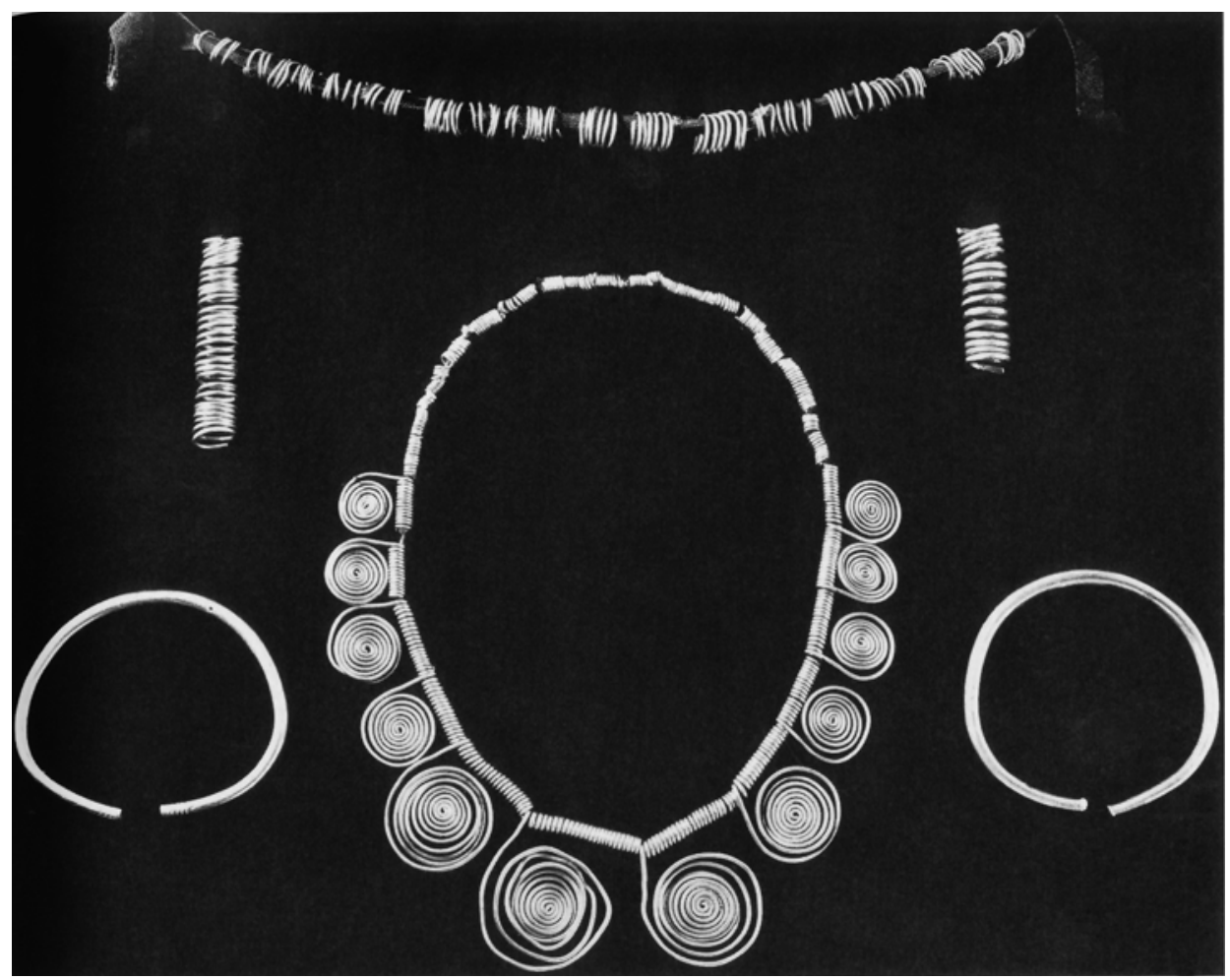

Obr. 6. Náhrdelník ze spirálových trubiček ze severoněmeckého Lorupu, počátek mladší doby bronzové. Podle Borchers 1968, 31, Taf. I:1.

Abb. 6. Halskette mit Spiralröhrchen aus Lorup, Norddeutschland, Anfang jüngere Bronzezeit. Nach Borchers 1968, 31, Taf. I:1.

Mezi analogiemi je nutno zmínit další drahocenný masivní zlatý řetěz (dlouhý $1,7 \mathrm{~m}$ a vážící skoro tři čtvrtě kilogramu) s mnoha závěsky ze sedmihradského Simleul Silvanei (Novotný a kol. 1986, 791-792), který časově spadá do období stěhování národů kolem roku 400. Patřil do majetku germánského, snad gepidského rodu a zřejmě souvisí s hunským vpádem. Řetěz je spleten ze tří drátů jako cop a hustě zdoben závěsky v podobě zmenšenin nástrojů, vinného listu či lidské postavy na člunu, v několika případech po dvou na jednom úchytu, tak jako v našem případě. Na nejdelším centrálním závěsu je zavěšena provrtaná a ozdobným úchytem opatřená křišt’álová perla (obr. 7).

Řetízek složený z tyčinek napojených navzájem očky s miniaturami železných zbraní, kleštěmi, sekyrou, medailonky či mincemi (původem z Indie) naznačuje víru v magické schopnosti nejen kovářů a kovolijců, ale i samého materiálu, s nímž pracovali; magické vlastnosti byly přisuzovány železu, bronzu i mosazi (Paine 2004, 157).

\section{Materiálový průzkum}

Základním cílem průzkumu bylo zjištění prvkového složení materiálu použitého pro zhotovení jednotlivých komponent řetízku. Za tímto účelem byla aplikována neinvazivní rentgenově fluorescenční spektrometrie (XRF). Vzhledem k dochovaným fragmentům železných klíčů, které tvoří ozdobné závěsky, jsme se rozhodli též k rentgenologickému průzkumu (rtg). Záměrem bylo posoudit zejména konstrukci zlomku většího klíče, ale i celkový rozsah korozního poškození. 


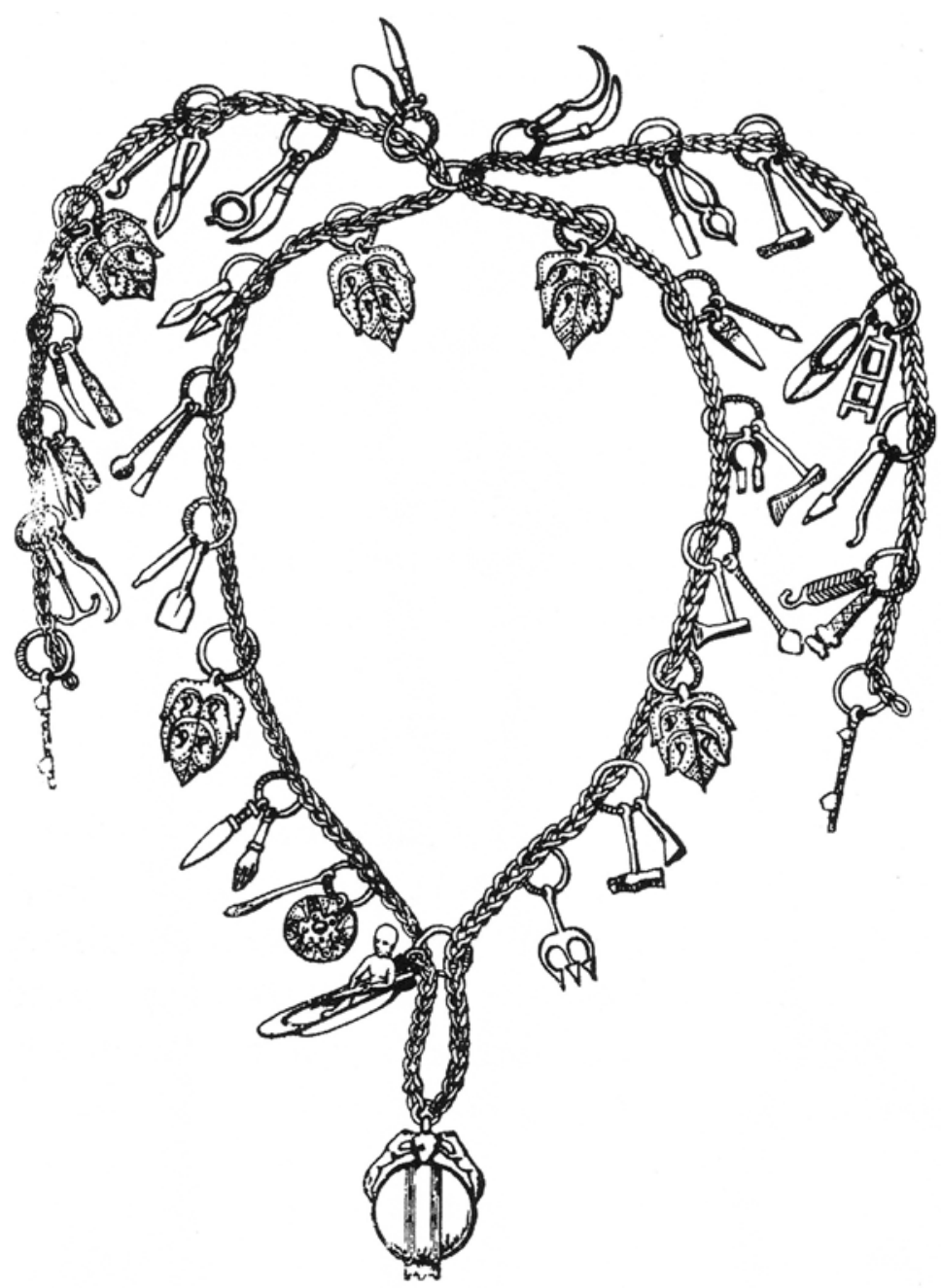

Obr. 7. Zlatý řetěz se závěsky ze Simleul Silvanei. Podle Novotný 1986, 792.

Abb. 7. Goldkette mit Anhängern aus Simleu Silvanei (Schomlenmarkt). Nach Novotný 1986, 792.

\section{Metodika analýz}

Předměty byly zhodnoceny pomocí rentgenové fluorescenční spektrometrie (XRF) na pracovišti Metodického centra konzervace Technického muzea v Brně. Použit byl ruční spektrometr DELTA Premium (výrobce Innov-X Systems) s budícím proudem rentgenky $200 \mu$ A (napětí rentgenky $40 \mathrm{kV}$ ). Jde o neinvazivní analýzu chemického složení povrchu zkoumaného materiálu. Výsledky chemického složení povrchové vrstvy mohou být proto ovlivněny korozními produkty, předchozím čištěním nebo technologickým zpracováním. Uvedené výsledky chemického složení analýzy XRF reprezentují vždy mediánovou hodnotu ze tří měření povrchu, s načítacím časem $30 \mathrm{~s}$.

Detektor př́stroje (SDD) je primárně kalibrován do plochy o průměru $3 \mathrm{~mm}^{2} \mathrm{~s}$ proudem rentgenky $200 \mu \mathrm{A}$ pro kvalitativně-kvantitativní analýzu prvků: Ti, V, Cr, Mn, $\mathrm{Fe}, \mathrm{Co}, \mathrm{Ni}, \mathrm{Cu}$, $\mathrm{Zn}, \mathrm{Zr}, \mathrm{Nb}, \mathrm{Ag}, \mathrm{Sn}, \mathrm{Bi}, \mathrm{Sb}, \mathrm{Hg}, \mathrm{Au}, \mathrm{Mg}, \mathrm{Al}, \mathrm{Si}, \mathrm{P}, \mathrm{S}$. Sekundární kalibrace se provádí pro linii $\mathrm{K}_{\alpha}$ Fe každých 24 hodin. 
Rtg snímkování bylo provedeno ve spolupráci s pracovníky Královopolská a.s. K prozařování bylo použito průmyslového rentgenu firmy Balteau (Baltographe 200) a filmy značky Kodak (Kodak IDUSTRIEX Film T200). ${ }^{2}$

Parametry rtg snímkování

\begin{tabular}{|c|c|c|c|c|c|}
\hline Artefakt & Materiál & Síla & Napětí & Proud & Čas \\
\hline \multirow{2}{*}{ Řetízek } & CuZn, Fe & $1-3 \mathrm{~mm}$ & $90 \mathrm{kV}$ & $10 \mathrm{~mA}$ & $60 \mathrm{~s}$ \\
\hline
\end{tabular}

Povrch řetízku s jednotlivými detaily spojů a části závěsů byly dokumentovány též za pomoci optického digitálního mikroskopu Keyence VHX 500 při uvedeném zvětšení.

\section{Výsledky materiálového průzkumu}

Pro zhotovení řetízku byl použit drátek o různém průměru. Spirály (různé délky 4 a $2 \mathrm{~cm}$ ) jsou z drátku o průměru ca $0,1 \mathrm{~cm}$, navinuté na tyčinky z dvojitého drátu o téže síle. Závěsky jsou přichyceny pomocí masivnějších háčků ze silnějšího drátku o průměru ca $0,15 \mathrm{~cm}$. Stejný drát je použit i pro sponu ve tvaru protáhlého očka. Povrch spirálek i háčků je pokryt stabilní hnědo-zelenou patinou korozních produktů uhličitanů mědi (Scott 2002). Místy se na něm vyskytují i korozní produkty železa, které pravděpodobně souvisejí s předchozím uložením předmětů v půdě a vzájemným kontaktem se železnými částmi náramku (obr. 8-9).

Fragment většího železného klíče (délka $3 \mathrm{~cm}$ ) je tvořen dutým dříkem o vnějším průměru ca $0,5 \mathrm{~cm}$ a prolamovanou hlavicí. Kovové jádro je poměrně zachovalé a pokryté korozními produkty černého minerálu magnetitu (Fe2O3). ${ }^{3}$ Místy jsou pouhým okem viditelné zbytky pájení mědí (obr. 10). Dochovaný tvar menšího železného klíče o celkové délce $2 \mathrm{~cm}$ je v zásadě již tvořen pouze hnědo-černými korozními produkty oxihydroxidů a oxidů železa. Na rtg snímku je zřetelný velmi dobře zachovalý korpus spirálovitých tyčinek s háčky a uvedenými částmi zkorodovaných železných závěsů (obr. 11).

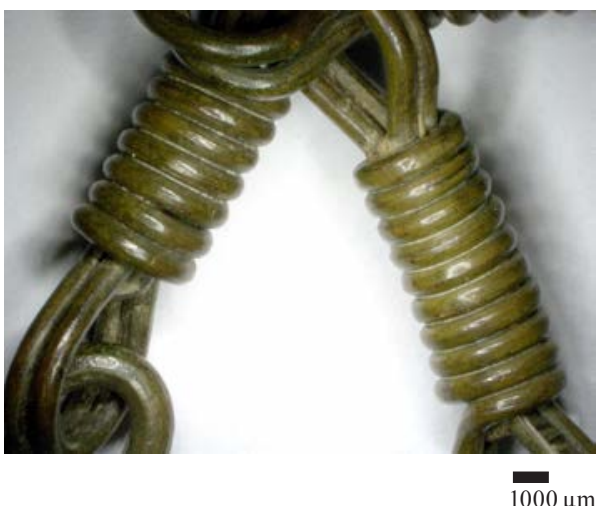

Obr. 8. Povrch závěsných spirálek se stabilní hnědo-zelenou patinou korozních produktů mědi. Mikrosnímek z digitálního mikroskopu Keyence VHX.

Abb. 8. Oberfläche der Anhängerspiralwicklung mit stabiler braun-grüner Patina der Korrosionsprodukte des Kupfers. Mikroaufnahme von einem Digital-Mikroskop Keyence VHX.

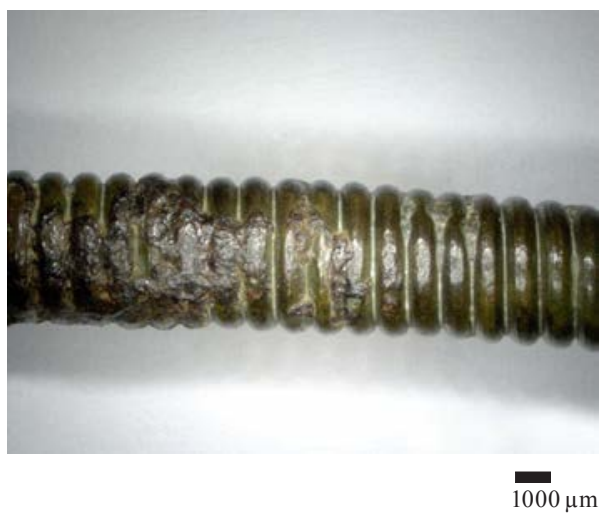

Obr. 9. Detail korozních produktů železa na povrchu spirálky řetízku. Mikrosnímek $\mathrm{z}$ digitálního mikroskopu Keyence VHX.

Abb. 9. Detail der Korrosionsprodukte des Eisens auf der Oberfläche der Spiralwicklung des Kettchens. Mikroaufnahme von einem Digital-Mikroskop Keyence VHX.

2 Za dodání rtg snímků děkujeme Mgr. Martinu Hložkovi, Ph.D., z Metodického centra konzervace Technického muzea v Brně.

3 Řetizek byl patrně již dřive čištěn od vnějších korozních produktů rzi. 


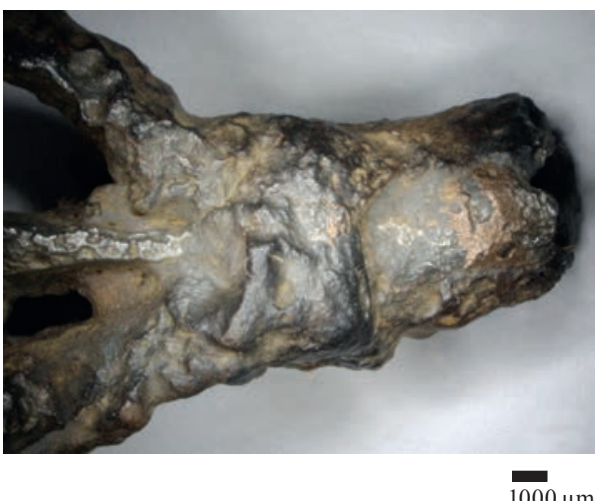

Obr. 10. Větší železný klíček se zbytky pájení mědí. Mikrosnímek z digitálního mikroskopu Keyence VHX.

Abb. 10. Größerer Eisenschlüssel mit Kupferlötfragmenten. Mikroaufnahme von einem Digital-Mikroskop Keyence VHX.

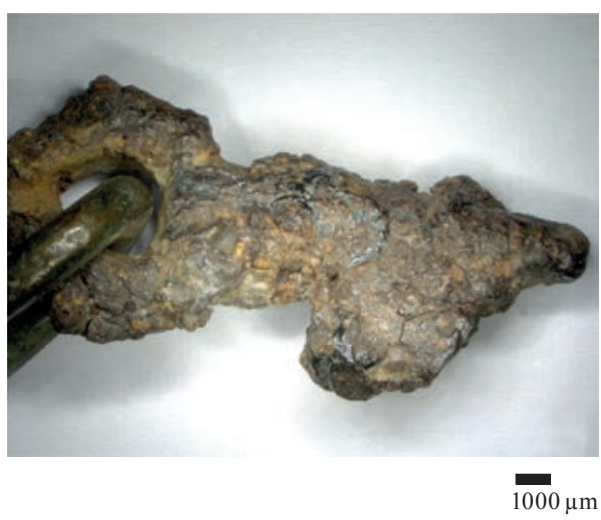

Obr. 11. Menší železný klíček. Mikrosnímek z digitálního mikroskopu Keyence VHX.

Abb. 11. Kleinerer Eisenschlüssel. Mikroaufnahme von einem Digital-Mikroskop Keyence VHX.

Při průzkumu materiálu řetízku byla vybrána pro XRF analýzu místa na závěsném háčku, delší spirále, kratší závěsné spirále (obr. 8-9) a větším železném klíči (obr. 10). Na základě výsledků analýzy lze konstatovat, že materiál drátku použitého pro zhotovení řetízku odpovídá mosazi - slitině mědi s obsahem zinku 14-15\% (tabulka č. 1). Z hlediska současného dělení mosazných slitin dle obsahu zinku jde spíše o slitinu zvanou tombak, která vyniká vysokou tvárností a používá se v bižuterii (Havlínová-Šilhová-Selucká a kol. 2011, 432-434). Přítomnost železa a fosforu souvisí pravděpodobně s povrchovou kontaminací předmětu. V př́ípadě niklu a cínu jde o př́měsový prvek, který zřejmě přešel do slitiny z rudy. Detekce chromu může být způsobena odezvou komory př́stroje.

Analýza rovněž potvrdila železný materiál většího klíče, který byl pájen (př́ípadně i plátován) mědí. Nižší koncentrace obsahu mědi jsou ovlivňovány omezenými možnostmi fokusace paprsku detektoru XRF př́ístroje.

\begin{tabular}{|c|c|c|c|c|c|c|c|c|}
\hline \multirow{2}{*}{ Č. měření, poloha analýzy } & \multicolumn{8}{|c|}{ Obsah prvku [hm. \%] } \\
\hline & $P$ & $\mathrm{Fe}$ & $\mathrm{Ni}$ & $\mathrm{Cu}$ & $\mathrm{Zn}$ & $\mathrm{Sn}$ & $\mathrm{Cr}$ & $\mathrm{Si}$ \\
\hline $\begin{array}{l}\text { 1. závěsný háček } \\
\text { 1. Aufhängehäkchen }\end{array}$ & 1,9 & 0,6 & 0,1 & 80,8 & 15,3 & 1,1 & - & - \\
\hline $\begin{array}{l}\text { 2. delší spirála } \\
\text { 2. längere Spirale }\end{array}$ & 1,7 & 0,5 & 0,1 & 82,4 & 13,9 & 1,1 & - & - \\
\hline $\begin{array}{l}\text { 3. kratší spirála } \\
\text { 3. kürzere Spirale }\end{array}$ & 6,4 & 0,6 & 0,1 & 82,3 & 13,9 & 1,0 & 0,1 & - \\
\hline $\begin{array}{l}\text { 4. větší klíč } \\
\text { 4. größerer Schlüssel }\end{array}$ & 0,2 & 88,4 & - & 5,6 & - & 0.1 & - & 5.6 \\
\hline
\end{tabular}

Tab. 1. Prvkové složení materiálu řetízku na základě XRF analýzy.

Tab. 1. Elementare Zusammensetzung des Kettchens laut RFA-Verfahren.

\section{Závěr a shrnutí}

Ve sbírkách archeologie středověku Moravského zemského muzea upoutal náš zájem řetízek z barevného kovu sestavený z pěti spirálek a opatřený původně zřejmě devíti závěsky, z nichž se zachovaly dva neurčitelné zlomky, jedna miniatura klíče a jeden neúplný, snad původně funkční 


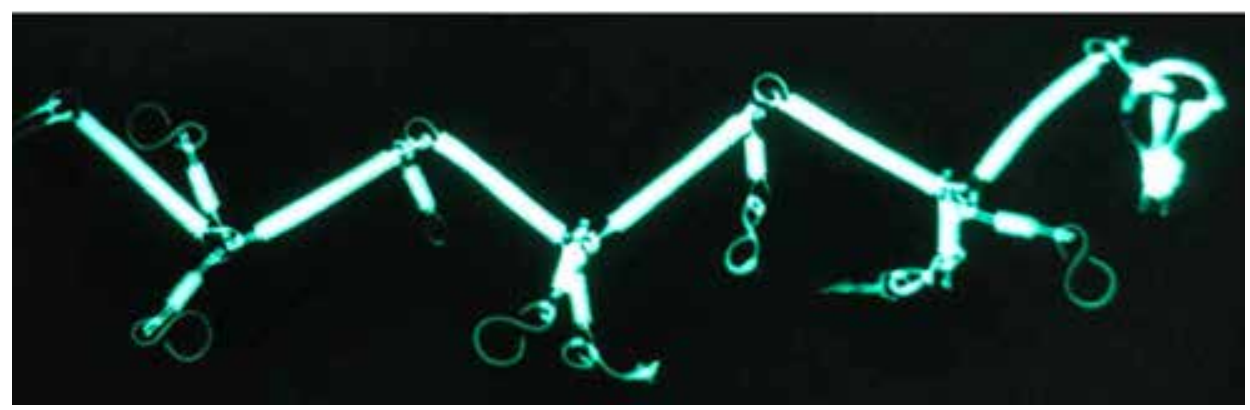

Obr. 12. Rentgenový snímek řetízku se závěsky.

Abb. 12. Röntgenaufnahme des Kettchens mit Anhängern.

klíček k závěsnému zámku či drobné skříňce, šperkovnici. Patří k muzejně nejstarším sbírkovým předmětům tohoto pracoviště (rok nabytí 1879). Zajímavé bylo hledání přesného místa a doby nálezu předmětu na hradě Veveří, při opravách komunikace pod hradem někdy v 70. letech 19. století, za majitelky kněžny Heleny Ypsilanti de Sina, kdy zdejší panství pomalu upadalo (Hodeček 2000, 253).

Snaha o ochranu před zlými silami provází člověka od nejhlubšího pravěku. Archeologické analogie nás zavádějí do etnicky germánského prostředí, které v novověku patří do oblasti přialpské. Zde se objevují zvláštní růžence coby specifická forma souboru amuletů, na nichž se kromě křest’anských symbolů vyskytují také apotropaika - předměty chránící majitele před zlými magickými vlivy démonických sil (Čermáková 2009, 192).

Materiálové analýzy potvrdily, že materiálem drátku použitého pro zhotovení řetízku je slitina mosazi s obsahem zinku okolo $14-15 \%$. Tento typ slitin se vyznačuje dobrou tvárností a je v dnešní terminologii označován jako tombak. U hodnoceného závěsku - železného klíče byly identifikovány stopy pájení, popř. plátování mědí. Na základě rentgenologického zhodnocení a posouzení charakteru korozních produktů byl dokladován velmi dobrý stav zachování mosazných částí řetízku. Bohužel u železných fragmentů je míra korozního narušení mnohem větší a není možné přesněji určit typologii závěsků.

Takové řetízky, většinou jako náramky, přetrvávají v určité podobě také v našem moderním světě a uchovávají si svou symbolicky upomínkovou či ochranitelskou funkci i dnes. Známy jsou v drahém kovu jako luxusní šperk, nebo jako dětská ozdůbka z bižuterie opatřená beruškami, podkůvkami, čtyřlístky, klíčky či srdíčky (tzv. žužu-náramky). Srovnávací i materiálové analýzy nás vedou k názoru, že hodnocený předmět představuje drobný šperk s výše zmíněnou funkcí a nejspíše jej lze datovat už do období (raného?) novověku.

Předložená práce vznikla za finanční podpory Ministerstva kultury ČR v rámci institucionálního financování na dlouhodobý koncepční rozvoj výzkumné organizace Moravské zemské muzeum (DKRVO, MK000094862).

\section{Literatura}

BORCHERS, W., 1968: Der bronzezeitliche Goldfund von Lorup und der frühmittelalterliche Fingerrring von Holzhausen im Städtischen Museum Osnabrück. In: Jahrbuch des Römisch-Germanischen Zentralmuseums Mainz 13, 1966, 30-33, taf. I. Mainz.

ČERMÁKOVÁ, E., 2009: Od středověkých amuletů k „žužu“ přívěskům. In: Křížová, A. a kol., Ornament oděv - šperk. Archaické projevy materiální kultury. Etnologické studie 5, 187-195. Brno: Masarykova univerzita.

EICHELR, K., 1891: Paměti panství veverského. Brno.

HODEČEK, D., 2000: Nástin dějin hradu Veveří, BMD 14, 227-258. 
HAVLÍNOVÁ, A.-ŠILHOVÁ, A.-SELUCKÁ, A. a kol., 2011: Konzervování a restaurování kovů. Ochrana předmětů kulturního dědictví z kovů a jejich slitin. Brno: Technické muzeum.

KRAJÍC, R., 1991: Stavební železo a uzavírací mechanismy na vrcholně středověkých lokalitách Táborska Eiserne Baubeschläge und Verschließungsmechanismen von den hochmittelalterlichen Lokalitäten in der Gegend von Tábor, AH 16, 323-344.

- 2003: Sezimovo Ústí. Archeologie středověkého poddanského města 3. Kovárna v Sezimově Ústí a analýza výrobků ze železa - Sezimovo Ústí. Archäologie der mittelalterlichen Untertanenstadt 3. Die Schmiede in Sezimovo Ústí und die Analyse der Produkte aus Eisen. Díl I, II. Praha - Sezimovo Ústí - Tábor.

NOVOTNÝ, B., a kol., 1986: Encyklopédia archeológie. Bratislava.

PAINE, S., 2004: Amulette, Geheimnisvolle Kräfte, Zauberglaube und Magie. Baden.

RICHTER, M.-KRAJÍC, R., 2001: Sezimovo Ústí. Archeologie středověkého poddanského města 2. Levobřežní předměstí - archeologický výzkum 1962-1988 - Sezimovo Ústí. Archäologie der mittelalterlichen Untertanenstadt 2. Vorstadt am linken Flussufer - Archäologische Untersuchung 1962-1988. Praha - Sezimovo Ústí - Tábor.

SCOTT, D., 2002: Copper and Bronze in Arts. Corrosion, Colorants, Conservation. Los Angeles: Getty Conservation Institute.

VITULA, P.-STRÁNSKÁ, R., 2006: Archeologické výzkumy na objektech ve správě NPÚ ÚOP v Brně v letech 2000-2006. In: Památková péče na Moravě - Monumentorum Moraviae Tutela 12, 7-36. Brno.

TRAPP, M., 1879: Funde in Mähren. Bericht des Conservators M. Trapp. In: Mittheilungen der k. k. Central-Commission zur Erforschung und Erhaltung der Kunst- und historischien Denkmale. V. Jahrgang, Neue Folge, CV-CX. Wien.

\section{Zusammenfassung}

\section{Ein Kettchen mit Anhängern von Burg Eichhorn bei Brünn}

Vor nicht langer Zeit wurden interessante Bandketten aus dem 16. Jahrhundert veröffentlicht, die in der Sammlung Archäologie des Mittelalter des Mährischen Landesmuseums aufbewahrt werden. Thematisch könnte man diesen noch eine weitere Kette aus dieser Sammlung zuordnen, diesmal offenbar eine Halskette mit mehreren Anhängern.

Das Buntmetallkettchen besteht aus fünf Spiralen und ist mit ursprünglich offenbar neun Anhängern versehen, von denen sich zwei unbestimmbare Fragmente erhalten haben. Ein Miniatur-Schlüssel und ein unvollständiger, ursprünglich wohl funktionsfähiger kleiner Schlüssel für ein Vorhängeschloss, eine Schatulle oder ein Schmuckkästchen. Interessant war die Suche nach dem genauen Fundort und Fundzeitpunkt des Gegenstandes auf der Burg Eichhorn (bei Veverská Bítýška nordwestlich von Brünn am heutigen Brünner Stausee) während den irgendwann in den siebziger Jahren des 19. Jahrhunderts unterhalb der Burg erfolgten Straßenreparaturarbeiten, als Fürstin Helena Ypsilanti de Sina Besitzerin der Burg war und sich die hiesige Herrschaft langsam im Niedergang befand (Hodeček 2000, 253). Archäologische Analogien führen uns in das ethnisch germanische Umfeld, das in der Neuzeit zum Alpenumland gehört. Dort tauchen eigentümliche Rosenkränze als spezielle Form einer Gruppe von Amuletten auf, auf denen neben christlichen Symbolen auch Apotropaika vorkommen, d.h. Gegenstände, die ihren Besitzer vor bösen magischen Einflüssen dämonischer Kräfte beschützen (Čermáková 2009, 192).

Materialanalysen haben bestätigt, dass es sich bei dem zur Fertigung des Kettchens verwendeten Material um eine Messinglegierung mit einem Zinngehalt von um die 14-15\% handelt. Dieser Legierungstyp zeichnet sich durch eine gute Formbarkeit aus und wird in der heutigen Terminologie als Tombak bezeichnet. An dem untersuchten Anhänger - einem Schlüssel aus Eisen - wurden Lötspuren, ggf. Spuren einer Kupferplattierung identifiziert. Anhand einer röntgenologischen Untersuchung und der Beurteilung des Charakters der Korrosionsprodukte wurde der sehr gute Erhaltungszustand der Messingteile des Kettchens nachgewiesen. Leider ist der Grad der Korrosionsstörung bei den Fragmenten aus Eisen um Vieles höher, was eine genauere Bestimmung der Typologie der Anhänger unmöglich macht. 
Solche Kettchen, bei denen es sich meist um Armbänder handelt, existieren auch in unserer Welt und behalten ihre symbolische Erinnerungs- oder Schutzfunktion bis in die Gegenwart bei. Im Edelmetall sind sie als Luxusschmuck für Erwachsene bekannt, oder als mit Marienkäfern, Kleeblättern, kleinen Schlüsseln oder Herzchen versehenem Modeschmuck für Kinder. Die Vergleichs- und die Materialanalysen bringen uns zur Ansicht, dass der untersuchte Gegenstand Kleinschmuck mit der oben erwähnten Funktion darstellt und höchstwahrscheinlich in die Neuzeit datiert werden kann.

Der vorliegende Artikel entstand mit finanzieller Unterstützung seitens des Kulturministeriums der Tschechischen Republik im Rahmen der institutionellen Finanzierung der langfristigen konzeptionellen Entfaltung der Forschungsinstitution (Mährisches Landesmuseum, MK000094862).

PhDr. Zdeňka Měchurová, CSc., Moravské zemské muzeum, Zelný trh 6, 65937 Brno, Česká republika, zmechurova@mzm.cz

Ing. Alena Selucká, Technické muzeum v Brně, Metodické centrum konzervace, Purkyňova 105, 61200 Brno, Česká republika, selucka@technicalmuseum.cz 
